\title{
Present Status and Perspective on the Future Use of Aflatoxin Biocontrol Products
}

\author{
Juan Moral ${ }^{1, *}$, Maria Teresa Garcia-Lopez ${ }^{1}$, Boris X. Camiletti ${ }^{2}$ (D), Ramon Jaime ${ }^{3}$, \\ Themis J. Michailides ${ }^{3}$, Ranajit Bandyopadhyay ${ }^{4}$ (D) and Alejandro Ortega-Beltran ${ }^{4, *}$ \\ 1 Departamento de Agronomía, ETSIAM, Universidad de Córdoba, Campus de Rabanales, 14014 Córdoba, \\ Spain; garlopter@gmail.com \\ 2 Microbiología Agrícola, FCA-UNC, IMBIV-CONICET, Córdoba X5000HUA, Argentina; \\ bcamiletti@gmail.com \\ 3 Kearney Agricultural Research and Extension Center, Department of Plant Pathology, University of \\ California-Davis, Parlier, CA 93648, USA; rjaime@ucanr.edu (R.J.); tjmichailides@ucanr.edu (T.J.M.) \\ 4 International Institute of Tropical Agriculture, PMB 5320, Ibadan 200001, Nigeria; \\ r.bandyopadhyay@cgiar.org \\ * Correspondence: juanmoralmoral@yahoo.es (J.M.); A.Beltran@cgiar.org (A.O.-B.)
}

Received: 24 February 2020; Accepted: 25 March 2020; Published: 1 April 2020

\begin{abstract}
Aflatoxin contamination of important food and feed crops occurs frequently in warm tropical and subtropical regions. The contamination is caused mainly by Aspergillus flavus and A. parasiticus. Aflatoxin contamination negatively affects health and trade sectors and causes economic losses to agricultural industries. Many pre- and post-harvest technologies can limit aflatoxin contamination but may not always reduce aflatoxin concentrations below tolerance thresholds. However, the use of atoxigenic (non-toxin producing) isolates of $A$. flavus to competitively displace aflatoxin producers is a practical strategy that effectively limits aflatoxin contamination in crops from field to plate. Biocontrol products formulated with atoxigenic isolates as active ingredients have been registered for use in the US, several African nations, and one such product is in final stages of registration in Italy. Many other nations are seeking to develop biocontrol products to protect their crops. In this review article we present an overview of the biocontrol technology, explain the basis to select atoxigenic isolates as active ingredients, describe how formulations are developed and tested, and describe how a biocontrol product is used commercially. Future perspectives on formulations of aflatoxin biocontrol products, along with other important topics related to the aflatoxin biocontrol technology are also discussed.
\end{abstract}

Keywords: aflatoxin; atoxigenic isolates; biocontrol technology; biocontrol agents

\section{Introduction}

\subsection{The Aflatoxin Problem}

Aflatoxin contamination of economically important food and feed crops occurs frequently in tropical and subtropical regions [1,2]. Susceptible crops include maize, groundnut, cottonseed, tree nuts, figs, and chilies, among others [3-5]. Aflatoxins are synthetized alone or with other mycotoxins by several Aspergillus species, most of them belonging to section Flavi (Table 1) [6]. However, A. flavus and A. parasiticus are the species most commonly associated with aflatoxin contamination of crops $[4,7]$. In general, toxigenic members of $A$. flavus produce aflatoxins $\mathrm{B}_{1}$ and $\mathrm{B}_{2}$ (blue fluorescent), while toxigenic members of $A$. parasiticus produce aflatoxins $G_{1}$ and $G_{2}$ (green fluorescent) in addition to $B_{1}$ and $B_{2}$ [7]. The most potent of the four aflatoxins is $B_{1}$. The four types of aflatoxins are associated with a myriad of health threats including stunting, impaired food conversion, immunosuppression, liver 
cancer, and, under acute exposure, death [8]. Similar negative impacts and low productivity occur in livestock when their feeds contain unsafe aflatoxin levels $[9,10]$. Most mycotoxin alerts reported in the European Union by the Rapid Alert System for Food and Feed [11] are raised by crop lots contaminated with aflatoxins, followed by ochratoxins (Figure 1).

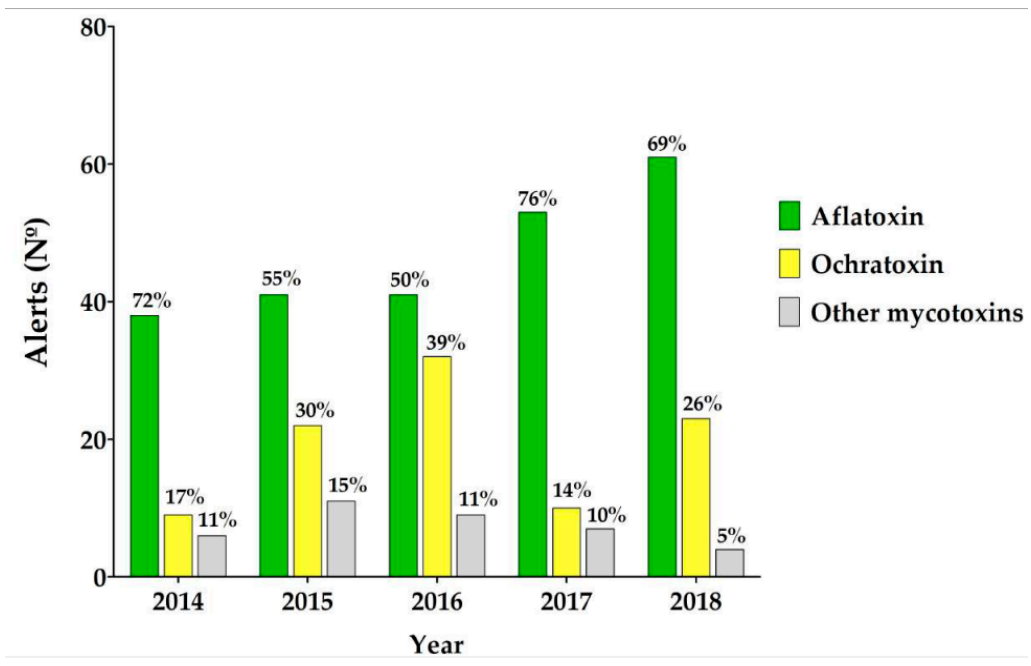

Figure 1. Number and relative percentage of mycotoxin alerts reported during the last five years (2014-2018) by the Rapid Alert System for Food and Feed (RASFF, 2019).

The magnitude of the aflatoxin contamination problem differs between developed and developing nations. Regulations and strict limits (tolerance levels) are enforced in developed nations to protect consumers from contaminated foods and feeds [12-15]. In contrast, regulations in emerging and developing nations, if they exist, are poorly enforced with few exceptions. Examples of exceptions include cases when the contamination levels reach a national health emergency, such as maize destruction in areas of Kenya, and the banning of several brands of maize flour and peanut butter in Kenya, Rwanda, and Uganda [16-19]. Therefore, in emerging and developing nations, most contaminated crops enter the food and feed chains, regardless of their aflatoxin content [3,20-25]. The absence of mechanisms to enforce aflatoxin tolerance levels results in chronic aflatoxin exposure with subsequent lack of access to markets, poverty, low well-being, poor economic growth, being among other constraints in the affected populations $[2,26,27]$. For all these reasons, in the developing world, contamination of food and feeds with aflatoxins has a profound negative impact on personal, social, and national development opportunities. 
Table 1. Toxigenic profile of aflatoxin-producing species within Aspergillus section Flavi. ${ }^{1}$.

\begin{tabular}{|c|c|c|c|c|c|c|}
\hline Species & $\begin{array}{l}\text { Aflatoxin } B_{1} \\
\qquad \& B_{2}\end{array}$ & $\begin{array}{l}\text { Aflatoxin } G_{1} \\
\quad \& G_{2}\end{array}$ & Aflatrem & $\mathrm{CPA}^{2}$ & 3-Nit-Acid ${ }^{3}$ & $\begin{array}{c}\text { Tenuazonic } \\
\text { Acid }\end{array}$ \\
\hline A. aflatoxiformans & + & + & + & + & - & - \\
\hline A. arachidicola & + & + & - & - & - & - \\
\hline A. austwickii & + & + & + & + & - & - \\
\hline A. cerealis & + & + & + & + & - & - \\
\hline A. flavus & + & +4 & + & + & + & - \\
\hline A. luteovirescens & + & + & - & - & - & + \\
\hline A. minisclerotigenes & + & + & + & + & - & - \\
\hline A. mottae & + & + & - & + & - & - \\
\hline A. nomius & + & + & - & - & - & + \\
\hline A. novoparasiticus & + & + & - & - & - & - \\
\hline A. parasiticus & + & + & - & - & - & - \\
\hline A. pipericola & + & + & + & + & - & - \\
\hline A. pseudocaelatus & + & + & - & + & - & + \\
\hline A. pseudonomius & + & + & - & - & - & + \\
\hline A. pseudotamarii & + & - & - & + & - & + \\
\hline A. sergii & + & + & + & + & - & - \\
\hline A. togoensis & + & - & - & - & - & - \\
\hline A. transmontanensis & + & + & - & - & - & - \\
\hline
\end{tabular}

\subsection{Technologies to Limit Aflatoxin Crop Contamination}

The notion that aflatoxin contamination is a problem restricted to post-harvest stages still incorrectly permeates in certain regions and sectors across the globe. Aflatoxin contamination usually starts in the field and, if post-harvest handling is deficient, aflatoxin concentrations can dramatically increase during storage $[22,24,26,29,30]$. Several cultural practices and technologies that prevent or limit the contamination process in the field are available for both highly mechanized and small-scale agricultural systems. Among the pre-harvest technologies are the use of atoxigenic isolates of A. flavus as biocontrol agents, insect control, timely harvesting, and use of less susceptible cultivars, including, in the case of maize and cotton, Bt-cultivars [31,32].

Regarding post-harvest technologies, sorting has been described as a successful practice to reduce aflatoxin contamination in grain (i.e., maize) and nut lots (i.e., groundnut, pistachio, almond). Removal of nuts and grains showing morphological characteristics associated with aflatoxin contamination (e.g., shriveled, discolored, early split, worm galleries) considerably reduces aflatoxin content in a sorted batch [33-35]. Chemical detoxification is mostly limited to human food, but some compounds (e.g., ammonium, hydrated bentonite, magnetic carbon) can reduce aflatoxin concentration in the final product [36]. Finally, other practices such as crop drying, improved sanitation, controlled processing and storage conditions, significantly contribute to reduce aflatoxin accumulation [22,24,26,30,37-40].

Due to the complexity and the multitude of factors affecting the aflatoxin contamination process, none of those technologies used individually provides complete protection. Rather than using a single or few somehow effective technologies, it is necessary to integrate aflatoxin management strategies addressing the entire crop production and distribution chain [14,41]. 


\subsection{Biocontrol as a Tool to Decrease Crop Aflatoxin Contamination}

Genetic diversity is large and aflatoxin production potential is highly variable within and among aflatoxin-producing species [7,42]. For example, populations of $A$. flavus are composed of aflatoxin producers and non-toxin-producing isolates (syn.: atoxigenic) (see 2.2). A. flavus is divided into two morphotypes, L and S, according to the size of sclerotia. The L morphotype produces few, large sclerotia $(>400 \mu \mathrm{m})$ while the $S$ morphotype produces large numbers of small sclerotia $(<400 \mu \mathrm{m})$ [43]. Isolates of the L morphotype are highly variable in aflatoxin-producing potential with some of them being atoxigenic, while $S$ morphotype isolates consistently produce high aflatoxin concentrations [44]. As with several fungal species, A. flavus populations can be classified in different vegetative compatibility groups (VCGs). Isolates belonging to the same VCG are genetically more closely related than isolates belonging to other VCGs. There are certain VCGs composed solely of atoxigenic isolates and those genetic groups are good candidates for biocontrol products that, when applied in the field at the right stage, can result in decreased aflatoxin content in the crop $[45,46]$.

Using atoxigenic $A$. flavus isolates as an active ingredient in biocontrol formulations is a safe, low-cost, easy-to-use, and effective technology to protect crops from aflatoxin contamination. Although it is highly effective, the use of biocontrol products must be combined with key aflatoxin management strategies available to farmers in any given region (e.g., technologies to reduce plant stress, to promote rapid drying, and optimal storage of the crop) to minimize the risk of contamination. The process of selecting atoxigenic isolates of $A$. flavus to use as biocontrol agents should follow a series of well-established steps ranging from selecting native and well-adapted isolates, determining the reasons for their inability to produce toxins (e.g., aflatoxins, cyclopiazonic acid [CPA]), and assessing their ability to out-compete aflatoxin producers under controlled and field conditions (Figure 2). Another criterion for selecting the most competitive isolates in field conditions is to evaluate their abilities to spread from soil to crops [47].



Figure 2. Illustration of the process to select atoxigenic isolates of Aspergillus flavus to develop aflatoxin biocontrol products.

When applied in the field, at the right crop phenological stage, atoxigenic biocontrol isolates displace aflatoxin-producers resulting in lowering infection rates by the native toxigenic isolates. Biocontrol treatment allows the production of crops with little to no aflatoxin, even in areas where 
both the environment and the pathogen population (density and toxigenicity) are conducive to crop infection and contamination. Frequently, treated crops contain undetectable aflatoxin content. Treatment allows producing crops that meet national and international premium market aflatoxin standards (below tolerance levels) that would be very difficult to achieve in the absence of the biocontrol treatment [48-53].

\subsection{From Single to Multiple Isolates}

The United States Department of Agriculture-Agricultural Research Service (USDA-ARS) developed the first biocontrol product, Aspergillus flavus AF36, which contains as the active ingredient an atoxigenic isolate native to Yuma, Arizona, US [54-56]. The biocontrol product AF36 was initially registered with the United States Environmental Protection Agency (USEPA) for use in cotton fields in Arizona and California, and subsequently the registration label was expanded to treat maize in Arizona and Texas [57]. AF36 is produced and distributed by the Arizona Cotton Research and Protection Council [48]. During a 10-year research effort, it was found both that VCG YV36, to which AF36 belongs, was the atoxigenic VCG most commonly encountered in California and that AF36 was successful in limiting aflatoxin content in commercially produced pistachio. Therefore, USEPA granted registration of AF36 for use in pistachio grown in California and Arizona (2012), and eventually (2017) in almond and fig in California $[15,51]$. The biocontrol product AF36 is now used in several states across the US, which makes it the most widely used aflatoxin biocontrol product in the world. A second biocontrol product, Afla-guard ${ }^{\circledR}$, containing a different atoxigenic $A$. flavus isolate (NRRL21882) as an active ingredient, was registered with USEPA for use in maize and groundnut in the US [58]. The product Afla-guard ${ }^{\circledR}$ is commercialized by Syngenta Crop Protection, Inc. (Greensboro, NC, USA) and has been used in experimental groundnut fields in Turkey [59].

The International Institute of Tropical Agriculture (IITA) and USDA-ARS, in collaboration with national and international institutions, adapted and improved the aflatoxin biocontrol technology for use in sub-Saharan Africa (SSA). Several aflatoxin biocontrol products that effectively reduce crop aflatoxin content have been developed under the trade name Aflasafe ${ }^{\circledR}[26,53]$, and several of those are currently commercialized in different nations in Africa [60]. Each Aflasafe ${ }^{\circledR}$ product contains, as active ingredient fungi, four atoxigenic isolates belonging to distinct VCGs native to the target nation. A shift from a single to a multiple-isolate product was made to exploit the repertoire of qualities that diverse atoxigenic isolates have in relationship to competitiveness and adaptation to diverse crops, environments, and agricultural practices [26,49,61]. Using isolates belonging to atoxigenic VCGs widely distributed and successful across environments and crops has proven to be effective in producing crops with low aflatoxin content $[46,47,53]$. In natural conditions, it has been noted that the dominance of single A. flavus VCGs over single and multiple areas, over multiple years, is transient [62]. Thus, use of multiple isolates may increase the chances to promote diverse atoxigenic communities over a longer-term.

USDA-ARS has developed a multi-isolate biocontrol product for use in maize grown in Texas, FourSure ${ }^{\mathrm{TM}}$, which contain, as active ingredients, four atoxigenic isolates native to Texas [63]. The US Texas Corn Producers Board is seeking the registration of FourSure [64]. In California, several atoxigenic VCGs have been identified by the University of California-Davis (UC Davis) in collaboration with USDA-ARS and different tree-nut growing organizations, and isolates in those VCGs are valuable resources as constituents of multi-isolate products to treat tree nut crops $[15,65,66]$. In North Carolina, combinations of atoxigenic strains have been tested in a field of a research station [67]. Research programs at UC Davis and collaborating universities in Argentina and Spain have identified through laboratory tests, atoxigenic $A$. flavus isolates with potential as biocontrol agents for use on those nations, but the efficacy of those isolates has not been tested under field conditions [68-70]. Similarly, studies for identifying potential A. flavus biocontrol isolates are being conducted in other countries including, China [71], India [72], Thailand [73,74], and Serbia [75]. 


\section{Basis for Selection of Atoxigenic Isolates as Biocontrol Agents}

\subsection{Use of Native Fungi}

Biocontrol formulations containing atoxigenic fungi native to target regions should have a greater chance to be more effective because of their adaptation to the environment, cropping system, and climatic and soil conditions [46,49]. Native atoxigenic isolates generally possess superior abilities to compete against other native microorganisms for local resources. Also, native fungi as active ingredients of products allow faster regulatory approval compared to exotic fungi [26,49]. As there are many atoxigenic $A$. flavus isolates in all nations where aflatoxin-producers thrive, there is no need to introduce exotic organisms. Moreover, native fungi are beneficial germplasm that governments can use/license in a manner considered the most appropriate to reduce aflatoxin contamination and aflatoxin exposure [49,61].

\subsection{Membership in VCGs That Are Completely Atoxigenic}

An important criterion when selecting atoxigenic fungi to develop a biocontrol product is that each candidate isolate must belong to a widely distributed VCG composed only of atoxigenic members [46,76,77]. Microbiological, chemical, and molecular tools are employed to find atoxigenic VCGs. Evaluation of aflatoxin-production abilities of a large number of A. flavus isolates from a given region is required; thousands of vegetative compatibility tests must be performed, and molecular analyses using simple sequence repeat (SSR) markers must be done to reveal whether a VCG has only atoxigenic members. These activities are both resource intensive and time-consuming but allow detecting VCGs composed exclusively of atoxigenic members.

\subsection{Lesions in the Aflatoxin Biosynthesis Gene Cluster}

About 30 clustered genes, and more than 20 enzymatic reactions, are needed for aflatoxin production [78,79]. In all aflatoxin-producing species, the aflatoxin biosynthesis cluster is located within a 75-kb region of chromosome 3 [78]. Genes in the cluster may be affected by different types of mutations, including substitutions, insertions, deletions, and frameshifts that can result in atoxigenicity. Deletions can be divided into specific deletions, affecting one gene, or large deletions affecting multiple or all aflatoxin biosynthesis genes [80,81]. For example, the aflatoxin and CPA biosynthesis gene clusters are entirely deleted in NRRL21882 [81] and one of the isolates, A. flavus Og0222, in the Aflasafe product used in Nigeria, [45]. Sometimes a single nucleotide polymorphism (SNP) is sufficient to confer atoxigenicity. A nonsense mutation (substitution: G-A) in the polyketide synthase gene is enough to confer atoxigenicity to the biocontrol isolate AF36, although there are many other mutations and deletions in the aflatoxin gene cluster of AF36 [45,82]. Finally, the aflatoxin gene cluster of A. oryzae, considered a domesticated species of $A$. flavus, shows several substitutions and frameshift mutations that result in lack of aflatoxin production [83].

\subsection{Area-Wide Adaptation}

Paramount is selection of atoxigenic fungi with known adaptation to target agroecosystems and their cropping systems [26]. There is large variability among VCGs in abilities to compete for crop substrates [84-86]. Numerous studies report isolates with potential as candidate atoxigenic biocontrol agents that were selected from small sets of isolates, and usually from relatively small areas. This can result in selection of isolates that may not be the most appropriate and widely adapted to limit aflatoxin contamination. Area-wide adaptation of atoxigenic VCGs can be revealed by examining several thousand $A$. flavus isolates associated with multiple crops collected in several hundred locations across a target country/region $[15,26,47]$. Such studies require intensive microbiological, chemical, and molecular tests. 


\subsection{Superior Competitiveness}

In controlled conditions, atoxigenic isolates with superior ability to limit aflatoxin contamination are identified by challenging the candidate atoxigenic isolates with high aflatoxin producers in co-inoculation assays. Typically, these assays are conducted by co-inoculating mature maize grains with both atoxigenic and aflatoxin-producing isolates. Subsequently, production of aflatoxin is quantified, and reduction of aflatoxin contamination is calculated with respect to grains inoculated only with an aflatoxin producing isolate [61,77]. Competition experiments have also been conducted using almond and pistachio kernels because those were the target crops [15].

Field testing allows evaluating aflatoxin reduction abilities of candidate fungi under field conditions [50-52,54,58]. When selecting atoxigenic fungi for multi-isolate products, field evaluations are done by applying atoxigenic isolates individually (typically 12 isolates are tested) and then, as part of a candidate multi-isolate products $[26,47,50]$. An evaluation of this type allows detecting those isolates with the greatest ability to create a founding population in the soil and then to successfully move to the grains or other harvested crop product in the treated fields [47]. In Nigeria, field evaluation of a candidate product prior to large-scale efficacy trials revealed that one of the tested isolates was a poor competitor across all tested environments and therefore was replaced with an isolate with superior potential as biocontrol agent [50].

\subsection{Efficacy Trials}

The true value of a biocontrol product composed of single or multiple isolates as active ingredient is revealed when the product is applied in crops managed by the farmers themselves, in multiple fields (usually 300 to 500) in multiple agro-ecological zones, and during multiple years $[51,87,88]$. Evaluating a product under controlled conditions, in a limited number of locations can result in incorrect interpretation regarding the benefits of biocontrol and its efficacy across environments [89].

Usually, researchers conduct evaluation trials using paired fields, treated vs. untreated. When paired fields are not sufficiently separated (e.g., by a distance of $>500 \mathrm{~m}$ ), untreated fields may be affected by cross-contamination with spores of the biocontrol isolate(s) dispersed from the adjoining treated fields. This effect is much higher in a traditional block design [90]. Aflatoxin contamination data of the paired fields often does not meet the requirements (normality and outliers) for applying a statistical paired T-test. In such cases, transforming the data or using a non-parametric Wilcoxon Signed Rank Test may provide some usable results.

\section{Registration of Products}

Many aflatoxin biocontrol products are currently registered with national biopesticide regulators for use in various crops (Table 2). In the US, AF36 is registered for use in several crops $[15,49,51]$, while Afla-guard ${ }^{\circledR}$ is registered for use in maize and groundnut [91]. In Africa, there are 14 atoxigenic biocontrol products registered under the tradename Aflasafe for use in maize; 13 of those products are also registered for use in groundnut, and two of those are registered for use in sorghum $[53,60]$. The African countries where Aflasafe products are registered are Nigeria, Kenya, Senegal, The Gambia, Burkina Faso, Ghana, Tanzania, Zambia, Mozambique, and Malawi. The atoxigenic biocontrol product $\mathrm{AF}-\mathrm{X} 1^{\circledR}$ is in the final stages of registration for unrestricted use in maize in Italy (http: //www.agronomico.com/AFX1.aspx; [52]). 
Table 2. List of aflatoxin biocontrol products registered for commercial use ${ }^{1}$.

\begin{tabular}{|c|c|c|c|c|c|}
\hline Product & $\begin{array}{l}\text { Atoxigenic Aspergillus flavus } \\
\text { Isolate(s) }\end{array}$ & $\begin{array}{l}\text { Responsible } \\
\text { Organization or Entity }\end{array}$ & Target Country & Crops for Use & Reference \\
\hline $\begin{array}{l}\text { Aspergillus flavus AF36 } \\
\text { Prevail }^{\mathbb{R}}\end{array}$ & AF36 & $\begin{array}{l}\text { Arizona Cotton Research } \\
\text { and Protection Council }\end{array}$ & US & $\begin{array}{l}\text { Cotton, maize, pistachio, } \\
\text { almond, and figs }\end{array}$ & {$[5,48,49,51]$} \\
\hline Afla-guard ${ }^{\circledR}$ & NRRL21882 & Syngenta ${ }^{\circledR}$ & US & Maize and groundnut & [91] \\
\hline Aflasafe $^{\mathrm{TM}}$ & Ka16127, La3279, La3304, Og0222 & IITA $^{3}$ & Nigeria & Maize and groundnut & [87] \\
\hline Aflasafe KE01'TM & C6-E, C8-F, E63-I, R7-H & IITA & Kenya & Maize & [45] \\
\hline Aflasafe SN01 & M2-7, M21-11, Ms14-19, Ss19-14 & IITA & Senegal and The Gambia & Maize and groundnut & {$[45,88]$} \\
\hline Aflasafe BF01 & M011-8, G018-2, M109-2, M110-7 & IITA & Burkina Faso & Maize and groundnut & [45] \\
\hline Aflasafe GH01 & $\begin{array}{l}\text { GHG079-4, GHG083-4, GHG321-2, } \\
\text { GHM174-1 }\end{array}$ & IITA & Ghana & $\begin{array}{l}\text { Maize, groundnut, and } \\
\text { sorghum }\end{array}$ & [47] \\
\hline Aflasafe GH02 & $\begin{array}{l}\text { GHM511-3, GHM109-4, GHM001-5, } \\
\text { GHM287-10 }\end{array}$ & IITA & Ghana & $\begin{array}{l}\text { Maize, groundnut, and } \\
\text { sorghum }\end{array}$ & [47] \\
\hline Aflasafe TZ01 & $\begin{array}{l}\text { TMS199-3, TMH104-9, TGS364-2, } \\
\text { TMH 30-8 }\end{array}$ & IITA & Tanzania & Maize and groundnut & $\begin{array}{l}\text { Unpublished registration } \\
\text { document }\end{array}$ \\
\hline Aflasafe TZ02 & $\begin{array}{l}\text { TMS64-1, TGS55-6, TMS205-5, } \\
\text { TMS137-3 }\end{array}$ & IITA & Tanzania & Maize and groundnut & $\begin{array}{l}\text { Unpublished registration } \\
\text { document }\end{array}$ \\
\hline Aflasafe MWMZ01 ${ }^{2}$ & $\begin{array}{l}\text { GP5G-8, GP1H-12, MZM594-1, } \\
\text { MZM029-7 }\end{array}$ & IITA & Mozambique & Maize and groundnut & $\begin{array}{l}\text { Unpublished registration } \\
\text { document }\end{array}$ \\
\hline Aflasafe MWMZ01 ${ }^{2}$ & $\begin{array}{l}\text { MW199-1, MW097-8, MW246-2, } \\
\text { MW238-2 }\end{array}$ & IITA & Malawi & Maize and groundnut & $\begin{array}{l}\text { Unpublished registration } \\
\text { document }\end{array}$ \\
\hline Aflasafe MZ02 & $\begin{array}{l}\text { GP5G-8, MZG071-6, MZM028-5, } \\
\text { MZM250-8 }\end{array}$ & IITA & Mozambique & Maize and groundnut & $\begin{array}{l}\text { Unpublished registration } \\
\text { document }\end{array}$ \\
\hline Aflasafe MW02 & $\begin{array}{l}\text { MW258-6, MW332-10, MW248-11, } \\
\text { MW204-7 }\end{array}$ & IITA & Malawi & Maize and groundnut & $\begin{array}{l}\text { Unpublished registration } \\
\text { document }\end{array}$ \\
\hline Aflasafe ZM01 & $\begin{array}{l}\text { 110MS-05, 38MS-03, 46MS-02, } \\
\text { 03MS-10 }\end{array}$ & IITA & Zambia & Maize and groundnut & $\begin{array}{l}\text { Unpublished registration } \\
\text { document }\end{array}$ \\
\hline Aflasafe ZM02 & $\begin{array}{l}\text { 31MS-12, 12MS-10, 47MS-12, } \\
\text { 64MS-03 }\end{array}$ & IITA & Zambia & Maize and groundnut & $\begin{array}{l}\text { Unpublished registration } \\
\text { document }\end{array}$ \\
\hline $\mathrm{AF}-\mathrm{X} 1^{\circledR}$ & MUCL54911 & Pioneer $^{\circledR}$ Int. & Italy & Maize & [52] \\
\hline
\end{tabular}

${ }^{1}$ All products contain sorghum as the carrier grain, except Afla-guard ${ }^{\circledR}$, which contains barley as the carrier [91]. ${ }^{2}$ Aflasafe MWMZ01 is a regional product developed for both Malawi and Mozambique; one native atoxigenic isolate from each of four vegetative compatibility groups co-distributed in both Mozambique and Malawi was selected. ${ }^{3}$ IITA, along with several partners, develops Aflasafe products for use in each nation; after registration, IITA licenses biocontrol manufacturing and commercialization responsibilities to private companies or the public sector [60]. 


\section{Delivery Methods}

\subsection{Grains as Carriers and Nutritional Sources.}

All commercially available biocontrol products are formulated using sterile grains that serve as carriers and as a nutritive source for the atoxigenic strains. Several formulations were tested at the earlier stages of biocontrol development, including inoculated rice and wheat grains, pasta granules (containing semolina, kaolin, and xanthan gum), maize flour-based granules, and alginate pellets containing several nutrients [43,92]. Spraying spore suspensions of the biocontrol agent directly to the canopy of the crop or applied as soil drenches were also tested $[43,93]$. However, the use of grains as carriers was found to be the best option $[43,92]$. Originally the formulations comprised sterilized grains colonized by the atoxigenic isolates $[48,50,91,94]$. Although this methodology was effective to deliver the biocontrol agent to the crop, it was expensive and slow to produce. Therefore, formulations using roasted or dehulled grains (to avoid germination) coated with a spore suspension of the biocontrol isolate(s) were developed [26,58,95]. Coated formulations lower the costs and increase the rate of product manufacture, making it more affordable for farmers.

Grain-based formulations were developed for applications in field crops (cotton, groundnut, maize) with small and closed canopies which provide good conditions for the biocontrol fungus to sporulate, but they might not be adequate for tree nut orchards with more open canopies which do not provide optimal conditions for a fungus to sporulate. Therefore, there is a need to develop alternative formulations and application methods that will deliver the biocontrol isolate(s) more efficiently in these less favorable environments.

\subsection{Use of Bioplastics}

To date, all commercial aflatoxin biocontrol products are formulated using grains of either barley, wheat, or sorghum as carrier of the spores of the atoxigenic isolates. Other alternatives have been sought in order to limit the use of food and feed grains. Recent studies have investigated whether coating seeds with a bioplastic containing an atoxigenic isolate may be a useful technology for delivering the biocontrol isolate in maize crops [96,97]. Before planting, maize seeds are film-coated using a starch-based bioplastic previously combined with spores of a biocontrol isolate. Moreover, chemical pesticides (insecticide or fungicides) might be added to the coating slurry for additional protection of seeds in soil. Application of the bioplastic seed-coating with spores favors initial growth of this starch-utilizing fungus, resulting in a decreased frequency of aflatoxin producers in soil. Subsequently, aflatoxin contamination of maize kernels during pre-harvest stages was reported to be reduced [97]. More studies describing key factors that may affect the effectiveness of this technology are needed to improve the performance of this formulation.

\subsection{Alternative Substrates}

The delivery method (i.e., barley, sorghum, or wheat grains) is the most expensive component of atoxigenic biocontrol products. In addition to bioplastics (see previous section), other substrates could be employed to reduce the production costs of the biocontrol products. This is particularly important for many smallholder resource-poor farmers, for which the cost to treat 1 ha of a crop may be prohibitive (12-18 USD, depending on the country) if they do not have access to markets paying a premium for safe crops. However, the major drawback of using grains as carriers is that they are frequently predated by ants, birds, and insects. Finding other substrates could reduce the cost of the product, have increased sporulation, and lower vulnerability to predation. The use of cassava peel pellets has been investigated to replace sorghum as a carrier and nutritive source for biocontrol isolates in West Africa, where large quantities of cassava peels are discarded daily [98]. However, spore yield on cassava peel substrate is low compared to sorghum, meaning a reduction in the effectiveness of the biocontrol product. More research is needed to determine which substrates could provide desirable features of increased sporulation under broader environmental conditions and that would be less 
prone to predation. Finally, two application methods without carrier have been studied. These are application of aqueous spore suspensions directly to the crop canopy or delivering the active ingredient through the irrigation system but evaluations in commercial orchards remain to be done [99].

\section{Effectiveness in Crops Treated with Biocontrol Products}

\subsection{Effectiveness of Aflatoxin Biocontrol Agents in Different Crops}

The efficacy of aflatoxin reduction by atoxigenic isolates of $A$. flavus has been demonstrated in various crops including maize, groundnut, cottonseed, and pistachio in the US, and maize, groundnut, and chili peppers in Africa $[48,51,91,100]$ (Table 2). Recently, efficacy trials have been conducted in sorghum in Ghana and sunflower in Tanzania and substantial reductions in aflatoxin have been achieved (unpublished results). Results of both field experiments and commercial treatments in cotton, maize, and groundnut fields show reduction in aflatoxin contamination ranging from $70 \%$ to $100 \%$ compared to adjacent non-treated fields [48,52,87,88,101,102]. In the commodities in which aflatoxin contamination is more frequent (i.e., the proportion of grains/seeds/fruits that can be contaminated by aflatoxin is higher), the impact of biocontrol isolates on aflatoxin reduction is higher too. Conversely, when the percentage of potential points of infection is meager, which occurs in the case of tree nut crops (i.e., from $1 / 5000$ to $1 / 20,000$ in pistachio kernels), the aflatoxin contamination on untreated fields is highly variable (measured as the variation coefficient) and, subsequently, the impact of the biocontrol agents in reducing aflatoxin contamination is frequently low but highly variable. Figure 3 shows the relationship between reduction of aflatoxin contamination as a result of application of atoxigenic A. flavus isolates in different commodities and the variation coefficient of aflatoxin contamination in untreated fields of these crops $[29,47,51,52,87,88,92,101,102]$.

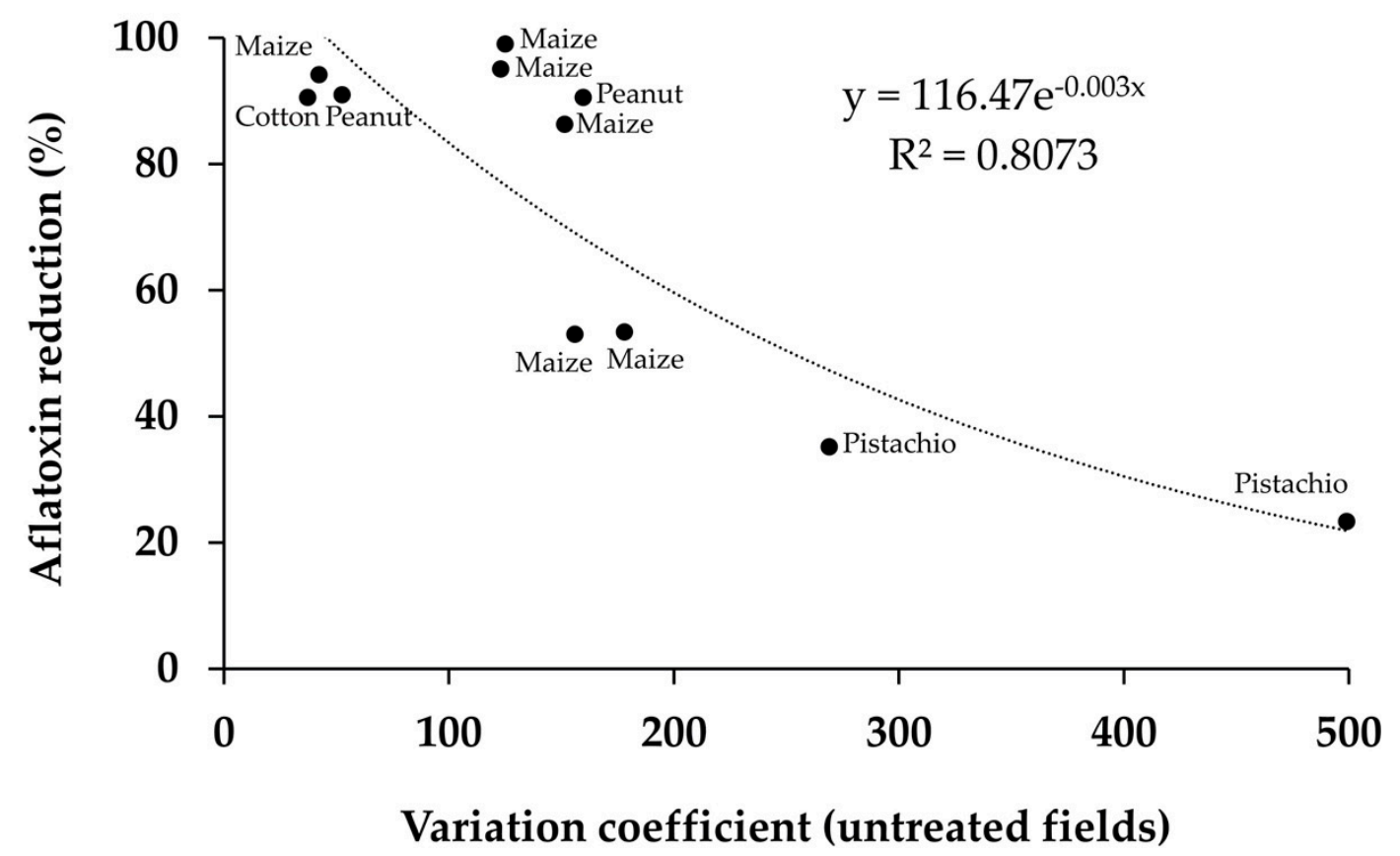

Figure 3. Relationship between aflatoxin reduction (\%) as a result of application of atoxigenic Aspergillus flavus isolates to different commodities and the variation coefficient of aflatoxin contamination found in untreated fields of these crops.

\subsection{Area-Wide Treatment for Increased Efficacy}

The overall goal of aflatoxin management with atoxigenic isolates is to change the population structure, typically dominated by aflatoxin producers, by increasing the frequencies of the applied 
atoxigenic isolates in the target ecosystem. Once the population is composed mainly of atoxigenic isolates, the aflatoxin production potential is greatly reduced.

A single application of an aflatoxin biocontrol product, at the right phenological stage, substantially reduces aflatoxin contamination in treated crops $[48,51,53]$. However, sometimes the biocontrol product does not completely protect the crop from aflatoxin contamination. Several factors affect the efficacy of treatment, including poor sporulation and product loss, which restrict the full potential of the competitive exclusion and founder effect principles of the technology $[95,99]$. Benefits of aflatoxin biocontrol applications go beyond reducing aflatoxin in the treated crop in a single season. Thus, biocontrol applications also increase the density of atoxigenic isolates in the soil, even in neighboring fields, and the carry-over effect has the potential to displace aflatoxin producers for subsequent seasons. On the other hand, toxigenic fungi residing in soils nearby treated fields can also contaminate the treated crops in subsequent seasons. Studies of the population structure of A. flavus at the area-wide scale began in the 1990s $[103,104]$ raising the idea that changing the population structure of the fungus at the regional scale will also reduce the aflatoxin-producing potential in the area. Implementing area-wide, long-term biocontrol programs might be the best strategy to reduce the population of aflatoxin-producing isolates for the medium- to long-term [29,48]. An area-wide and long-term aflatoxin management program will require treating most aflatoxin susceptible crops growing in the same area. However, effective aflatoxin control might be achieved with partial, booster treatments after initial application for a few years. With area-wide treatment, biocontrol products would need to be reapplied perhaps at a lower dose to maintain a population with low aflatoxin production potential in an area-wide long-term management program. However, the application frequency depends on the characteristics of each area, since areas differ in the time that the biocontrol will persist in the soil $[102,104]$.

\section{Biocontrol Performance in Future Scenarios}

An understanding of the epidemiology of, and the interaction between biocontrol agents and aflatoxin producers under field conditions is essential for successful simulation modelling in future scenarios, particularly under climate change. Simulation models to predict future toxigenic and atoxigenic population scenarios to assist farmers and pest control advisers through Decision Support Systems (DSS) will be important tools. Climate changes that accompany projected increments in atmospheric $\mathrm{CO}_{2}$ can lead to a reduction in water availability in agricultural areas. Thus, by 2100 , predictions indicate a rise in global temperature between 1 and $5{ }^{\circ} \mathrm{C}$, which will affect development of crops and their capacity to adapt along with changes in the current distribution and densities of aflatoxin-producing fungi [105]. Areas affected by severe water stress (criticality ratio: withdrawals/availability of water $>0.4$ ) will expand and the stress will intensify [106]. Changes in global precipitation, ecological, and crop system patterns may alter the compositions of Aspergillus populations and their fitness, since they are primarily influenced by temperature and soil moisture. Jaime-Garcia and Cotty [107] observed spatial and temporal variations in aflatoxin contamination depending primarily on those environmental factors. For example, soil surface temperature influences fungal communities with propagule density decreasing when daily average soil temperature is either below $18{ }^{\circ} \mathrm{C}$ or above $30^{\circ} \mathrm{C}$ [108]. A. flavus S morphotype fungi are more likely to occur at a higher proportion during warmer, drier years, and consequently, increased aflatoxin concentrations in crops occur because of their high aflatoxin-producing potential [44]. Monitoring climatic parameters and crop aflatoxin accumulation across countries will contribute to a better understanding of the influences of climate change on aflatoxin contamination risks [26]. Information on the interaction between the environment and the fungal population size and structure will allow the implementation of aflatoxin management strategies based on weather events, which may include a requirement for selection of atoxigenic VCGs adapted to both hotter, drier climates and changes in cropping cycles [44]. 


\section{Losses to Bird, Insect, or Rodent Predation}

Using grains as carriers for biocontrol isolates consistently reduces aflatoxin contamination in field crops (maize, cotton, groundnut, chili peppers), where closed canopies create conditions of humidity for good sporulation of the biocontrol product when applied at the right time. However, when conditions are not conducive for rapid sporulation, the product is exposed to predation by birds, insects, ants, and rodents [29]. Under conditions found in tree nut orchards, predation of the biocontrol product is even greater since the ground is frequently bare of vegetation, leaving the product exposed to animal and insect predation. Preliminary studies conducted in California, at Kearney Agricultural Research and Extension Center, indicate that besides ants, other arthropods (mainly Oniscidea spp.) are implicated in the rapid loss of formulated grain carriers [99]. Dissimilar agricultural management practices (e.g., crop densities, irrigation strategies, tillage, and maintenance of vegetative cover) are essential factors affecting the fauna found in the orchard. Furthermore, grain carriers could spoil when exposed to excessive moisture in the soil, a condition that favors rapid colonization by other fungi (e.g., Fusarium spp.), thus impeding the sporulation of the biocontrol agent(s). Biocontrol efficacy can be further enhanced with innovations in formulations that improve the efficiency of sporulation and reduce the proportion of grains lost due to predation.

\section{Concerns Posed for Using Biocontrol Products}

Isolates used in biocontrol formulations belong to ancient, highly stable atoxigenic VCGs selected through carefully designed and elaborate microbiological, chemical, molecular, and field studies [47, $50,53,76,77]$. Well-planned studies have demonstrated that members of an atoxigenic VCG do not exchange genetic material with members of other VCGs (either toxigenic or atoxigenic) despite plenty of opportunities for exchange of genetic material in both treated and non-treated areas $[42,76,109,110]$. Clonality is the predominant mode of $A$. flavus reproduction. Recombination events between members of toxigenic and atoxigenic VCGs have been reported only in laboratory and field studies under specific conditions [111-115] and is rare in nature. Therefore, the risk for recombination and generation of toxigenic variants when applying atoxigenic isolates in the field is minimal.

No major health problems have been reported due to the use and application of biocontrol agents by field workers, but it can cause allergic reaction in some individuals. In general, workers should avoid a prolonged contact with the product through the skin and eyes, avoiding those periods in which a high concentration of spores is expected.

\section{Conclusions}

Whereas some researchers have critical opinion regarding biocontrol of aflatoxins [116-120], substantial research conducted with field and tree crops has shown that using atoxigenic isolates of $A$. flavus as biocontrol agents is one of the most effective pre-harvest management strategies for reducing aflatoxin contamination (Figure 3). The extensive research demonstrating the efficacy, safety, and benefits of the technology have allowed registration of several aflatoxin biocontrol products with regulatory authorities. Following registration, large-scale use is possible after developing infrastructure to produce the biocontrol product on a large-scale, developing sound commercialization strategies, transferring the technology to appropriate industries, and implementing innovative marketing and distribution channels $[48,60,87]$. It is worth mentioning that this management strategy is especially useful in food-insecure regions with rapidly growing populations in Africa, which also suffer major losses in agriculture due to pests and diseases [121], and where farmers' access to other control methods is much more restricted. Hundreds of thousands of farmers and diverse crop industries benefiting from the technology consider biocontrol products as vital tools to produce crops with reduced aflatoxin contamination. The use of biocontrol and other aflatoxin management strategies allow farmers to produce safe crops for their own consumption and/or to sell to premium markets. 
Aflatoxin biocontrol products have been developed for use in a fraction of the crops susceptible to aflatoxin contamination. Adapting, testing, and validating the biocontrol technology for use in other susceptible crops (e.g., sesame seed, hazelnut, millet) would provide health, trade, and economic benefits for producers, consumers, and processors of these crops.

Author Contributions: J.M. and A.O.-B. conceptualized the idea after J.M. received the invitation from the journal; A.O.-B., J.M., T.J.M., and R.B. wrote the manuscript; M.T.G.-L., B.X.C., R.J. provided input to different sections of the manuscript. A.O.-B, J.M., R.B., and T.J.M. finalized the manuscript. All authors have read and agreed to the published version of the manuscript.

Funding: No external funding was received to write the manuscript.

Acknowledgments: We acknowledge the anonymous reviewers for their valuable comments and suggestions. J.M. was partially supported by a H2020 Marie Skłodowska-Curie Actions fellowship launched by the European Union. M.T.G.-L. was supported by the SICYT foundation from Asturias. B.X.C. was partially supported by the Argentinean National Scientific and Technical Research Council (CONICET) through a postdoctoral fellowship. J.M., M.T.G.-L., B.X.C., R.J., and T.J.M. were partially supported by the California Pistachio Research Board, the Almond Board of California, and the California Fig Institute. R.B. and A.O.-B. were partially supported by CGIAR Research Program on Agriculture for Nutrition and Health (A4NH).

Conflicts of Interest: The authors receive no direct financial benefit from the manufacturing and marketing of any aflatoxin biocontrol products mentioned in this review article. The Aflasafe name is a Trademark of the International Institute of Tropical Agriculture (IITA). IITA used to manufacture and commercialize Aflasafe for use in Nigeria, Senegal, Burkina Faso, The Gambia, and Ghana. Manufacturing and distribution responsibilities have been licensed to the private or public sector. IITA charges a small licensing fee to manufacturers for use of the Aflasafe name and cost associated with technology transfer and technical backstopping. R.B. and A.O.-B. are employed by IITA. The rest of the authors declare that there are no commercial or financial relationships that could be interpreted as potential conflicts of interest.

\section{References}

1. Klich, M.A. Environmental and developmental factors influencing aflatoxin production by Aspergillus flavus and Aspergillus parasiticus. Mycoscience 2007, 48, 71-80. [CrossRef]

2. JECFA. Safety Evaluation of Certain Contaminants in Food: Prepared by the Eighty-Third Meeting of the Joint FAO/WHO Expert Committee on Food Additives (JECFA); WHO Food A; World Health Organization and Food and Agriculture Organization of the United Nations: Geneva, Switzerland, 2018; ISBN 9241660554.

3. Bandyopadhyay, R.; Kumar, M.; Leslie, J.F. Relative severity of aflatoxin contamination of cereal crops in West Africa. Food Addit. Contam. 2007, 24, 1109-1114. [CrossRef]

4. Amaike, S.; Keller, N.P. Aspergillus flavus. Annu. Rev. Phytopathol. 2011, 49, 107-133. [CrossRef] [PubMed]

5. Ortega-Beltran, A.; Moral, J.; Puckett, R.; Morgan, D.; Cotty, P.J.; Michailides, T.J. Fungal communities associated with almond throughout crop development: Implications for aflatoxin biocontrol management in California. PLoS ONE 2018, 13, 1-15. [CrossRef] [PubMed]

6. Frisvad, J.C.; Hubka, V.; Ezekiel, C.N.; Hong, S.B.; Nováková, A.; Chen, A.J.; Arzanlou, M.; Larsen, T.O.; Sklenár, F.; Mahakarnchanakul, W.; et al. Taxonomy of Aspergillus section Flavi and their production of aflatoxins, ochratoxins and other mycotoxins. Stud. Mycol. 2019. [CrossRef] [PubMed]

7. Klich, M.A. Aspergillus flavus: The major producer of aflatoxin. Mol. Plant Pathol. 2007, 8, 713-722. [CrossRef]

8. Azziz-Baumgartner, E.; Lindblade, K.; Gieseker, K.; Rogers, H.S.; Kieszak, S.; Njapau, H.; Schleicher, R.; McCoy, L.F;; Misore, A.; DeCock, K.; et al. Case-control study of an acute aflatoxicosis outbreak, Kenya, 2004. Environ. Health Perspect. 2005, 113, 1779-1783. [CrossRef]

9. Bryden, W.L. Mycotoxin contamination of the feed supply chain: Implications for animal productivity and feed security. Anim. Feed Sci. Technol. 2012, 173, 134-158. [CrossRef]

10. Monson, M.; Coulombe, R.; Reed, K. Aflatoxicosis: Lessons from toxicity and responses to aflatoxin B1 in poultry. Agriculture 2015, 5, 742-777. [CrossRef]

11. RASFF: Food and Feed Safety Alerts. European Commission, 2019. Available online: https://webgate.ec. europa.eu/rasff-window/portal/?event=notificationsList\&StartRow=1 (accessed on 10 November 2019).

12. Wu, F. Global impacts of aflatoxin in maize: Trade and human health. World Mycotoxin J. 2015, 8, 137-142. [CrossRef] 
13. Van de Perre, E.; Jacxsens, L.; Lachat, C.; El Tahan, F.; De Meulenaer, B. Impact of maximum levels in European legislation on exposure of mycotoxins in dried products: Case of aflatoxin B1 and ochratoxin A in nuts and dried fruits. Food Chem. Toxicol. 2015, 75, 112-117. [CrossRef] [PubMed]

14. Logrieco, A.F.; Miller, J.D.; Eskola, M.; Krska, R.; Ayalew, A.; Bandyopadhyay, R.; Battilani, P.; Bhatnagar, D.; Chulze, S.; De Saeger, S.; et al. The mycotox charter: Increasing awareness of, and concerted action for, minimizing mycotoxin exposure worldwide. Toxins 2018, 10, 149. [CrossRef] [PubMed]

15. Ortega-Beltran, A.; Moral, J.; Picot, A.; Puckett, R.D.; Cotty, P.J.; Michailides, T.J. Atoxigenic Aspergillus flavus isolates endemic to almond, fig, and pistachio orchards in California with potential to reduce aflatoxin contamination in these crops. Plant Dis. 2019, 103, 905-912. [CrossRef] [PubMed]

16. Lubanga, D.; Bii, B. KEBS Bans 5 Maize Flour Brands over High Aflatoxin Levels. Daily Nation. 2019. Available online: https://www.nation.co.ke/news/Kebs-bans-5-maize-flour-brands/1056-5343060-eb9k78/index.html (accessed on 9 November 2019).

17. Mwakio, P. State to Destroy 9.4 Tonnes of Contaminated Maize in Mombasa. Stand Digit. 2019. Available online: https://www.standardmedia.co.ke/article/2001309356/state-to-destroy-9-4-tonnes-of-contaminatedmaize-in-mombasa (accessed on 14 January 2020).

18. Omulo, C. Rwanda Bans Seven Peanut Butter Brands from Kenya. Businiss Daily. 2019. Available online: https://www.businessdailyafrica.com/news/Rwanda-bans-peanut-butter-brands-Kenya/5395465345834-nyxhrl/index.html (accessed on 12 November 2019).

19. CGTM Africa. Rwanda, Uganda Ban Kenyan-Produced Peanut Butter. CGTN Africa. 2019. Available online: https:/africa.cgtn.com/2019/11/14/rwanda-uganda-ban-kenyan-produced-peanut-butterover-contamination-fears/ (accessed on 14 November 2019).

20. Guan, S.; Gong, M.; Yin, Y.; Huang, R.; Ruan, Z.; Zhou, T.; Xie, M. Occurrence of mycotoxins in feeds and feed ingredients in China. J. Food Agric. Environ. 2011, 9, 163-167. [CrossRef]

21. Probst, C.; Bandyopadhyay, R.; Cotty, P.J. Diversity of aflatoxin-producing fungi and their impact on food safety in sub-Saharan Africa. Int. J. Food Microbiol. 2014, 174, 113-122. [CrossRef] [PubMed]

22. Waliyar, F.; Osiru, M.; Ntare, B.R.; Kumar, K.V.K.; Sudini, H.; Traore, A.; Diarra, B. Post-harvest management of aflatoxin contamination in groundnut. World Mycotoxin J. 2015, 8, 245-252. [CrossRef]

23. Njoroge, S.M.C.; Matumba, L.; Kanenga, K.; Siambi, M.; Waliyar, F.; Maruwo, J.; Machinjiri, N.; Monyo, E.S. Aflatoxin B1 levels in groundnut products from local markets in Zambia. Mycotoxin Res. 2017, 33, 113-119. [CrossRef]

24. Seetha, A.; Munthali, W.; Msere, H.W.; Swai, E.; Muzanila, Y.; Sichone, E.; Tsusaka, T.W.; Rathore, A.; Okori, P. Occurrence of aflatoxins and its management in diverse cropping systems of central Tanzania. Mycotoxin Res. 2017, 33, 323-331. [CrossRef]

25. Lindahl, J.F.; Kagera, I.N.; Grace, D. Aflatoxin M1 levels in different marketed milk products in Nairobi, Kenya. Mycotoxin Res. 2018, 34, 289-295. [CrossRef]

26. Bandyopadhyay, R.; Ortega-Beltran, A.; Akande, A.; Mutegi, C.; Atehnkeng, J.; Kaptoge, L.; Senghor, L.A.; Adhikari, B.N.; Cotty, P.J. Biological control of aflatoxins in Africa: Current status and potential challenges in the face of climate change. World Mycotoxin J. 2016, 9, 771-789. [CrossRef]

27. Leroy, J.L.; Sununtnasuk, C.; García-Guerra, A.; Wang, J.S. Low level aflatoxin exposure associated with greater linear growth in southern Mexico: A longitudinal study. Matern. Child Nutr. 2018, 14, 1-7. [CrossRef] [PubMed]

28. Klich, M.A. Identification of Common Aspergillus Species; Centraalbureau Voor Schimmelcultures: Utrecht, The Netherlands, 2002; p. 116.

29. Cotty, P.J.; Probst, C.; Jaime-Garcia, R. Etiology and management of aflatoxin contamination. In Mycotoxins: Detection Methods, Management, Public Health and Agricultural Trade; Leslie, J.F., Bandyopadhayay, R., Visconti, A., Eds.; CAB International: Wallingford, UK, 2008; pp. 287-299, ISBN 9781845930820.

30. Mahuku, G.; Nzioki, H.S.; Mutegi, C.; Kanampiu, F.; Narrod, C.; Makumbi, D. Pre-harvest management is a critical practice for minimizing aflatoxin contamination of maize. Food Control 2019, 96, 219-226. [CrossRef] [PubMed]

31. Abbas, H.K.; Accinelli, C.; Zablotowicz, R.M.; Abel, C.A.; Bruns, H.A.; Dong, Y.; Shier, W.T. Dynamics of mycotoxin and Aspergillus flavus levels in aging Bt and non-Bt corn residues under Mississippi no-till conditions. J. Agric. Food Chem. 2008, 56, 7578-7585. [CrossRef] [PubMed] 
32. Abbas, H.K.; Wilkinson, J.R.; Zablotowicz, R.M.; Accinelli, C.; Abel, C.A.; Bruns, H.A.; Weaver, M.A. Ecology of Aspergillus flavus, regulation of aflatoxin production, and management strategies to reduce aflatoxin contamination of corn. Toxin Rev. 2009, 28, 142-153. [CrossRef]

33. Doster, M.A.; Michailides, T.J. Aspergillus molds and aflatoxins in pistachio nuts in California. Phytopathology 1994, 84, 583-590. [CrossRef]

34. Whitaker, T.B.; Dorner, J.W.; Lamb, M.; Slate, A.B. The effect of sorting farmers' stock peanuts by size and color on partitioning aflatoxin into various shelled peanut grade sizes. Peanut Sci. 2005, 32, 103-118. [CrossRef]

35. Matumba, L.; Van Poucke, C.; Njumbe Ediage, E.; Jacobs, B.; De Saeger, S. Effectiveness of hand sorting, flotation/washing, dehulling and combinations thereof on the decontamination of mycotoxin-contaminated white maize. Food Addit. Contam. Part A Chem. Anal. Control. Expo. Risk Assess. 2015, 32, 960-969. [CrossRef]

36. Peng, Z.; Chen, L.; Zhu, Y.; Huang, Y.; Hu, X.; Wu, Q.; Nüssler, A.K.; Liu, L.; Yang, W. Current major degradation methods for aflatoxins: A review. Trends Food Sci. Technol. 2018, 80, 155-166. [CrossRef]

37. Campbell, B.C.; Molyneux, R.J.; Schatzki, T.F. Current research on reducing pre- and post-harvest aflatoxin contamination of U.S. almond, pistachio, and walnut. J. Toxicol. Toxin Rev. 2003, 22, 225-266. [CrossRef]

38. Jaime-Garcia, R.; Cotty, P.J. Aspergillus flavus in soils and corncobs in south Texas: Implications for management of aflatoxins in corn-cotton rotations. Plant Dis. 2004, 88, 1366-1371. [CrossRef]

39. Hell, K.; Fandohan, P.; Bandyopadhyay, R.; Kiewnick, S.; Sikora, R.; Cotty, P.J. Pre- and post-harvest management of aflatoxin in maize: An African perspective. In Mycotoxins: Detection Methods, Management, Public Health and Agricultural Trade; Leslie, J.F., Bandyopadhyay, R., Visconti, A., Eds.; CAB International: Wallingford, UK, 2008; p. 219, ISBN 9781845930820.

40. Diao, E.; Dong, H.; Hou, H.; Zhang, Z.; Ji, N.; Ma, W. Factors influencing aflatoxin contamination in before and after harvest peanuts: A review. J. Food Res. 2014, 4, 148-154. [CrossRef]

41. Ayalew, A.; Kimanya, M.; Matumba, L.; Bandyopadhyay, R.; Menkir, A.; Cotty, P.J. Controlling aflatoxins in maize in Africa: Strategies, challenges and opportunities for improvement. In Achieving Sustainable Cultivation of Maize. Volume 2: Cultivation Techniques, Pest and Disease Control; Watson, D., Ed.; Burleigh Dodds Science Publishing: Cambridge, MA, USA, 2017; pp. 1-24.

42. Grubisha, L.C.; Cotty, P.J. Genetic isolation among sympatric vegetative compatibility groups of the aflatoxin-producing fungus Aspergillus flavus. Mol. Ecol. 2010, 19, 269-280. [CrossRef] [PubMed]

43. Cotty, P.J.; Bayman, D.S.; Egel, D.S.; Elias, K.S. Agriculture, Aflatoxins and Aspergillus. In The Genus Aspergillus; Powell, K., Ed.; Plenum Press: New York, NY, USA, 1994; pp. 1-27.

44. Cotty, P.J.; Jaime-Garcia, R. Influences of climate on aflatoxin producing fungi and aflatoxin contamination. Int. J. Food Microbiol. 2007, 119, 109-115. [CrossRef] [PubMed]

45. Adhikari, B.N.; Bandyopadhyay, R.; Cotty, P.J. Degeneration of aflatoxin gene clusters in Aspergillus flavus from Africa and North America. AMB Express 2016, 6, 62. [CrossRef]

46. Atehnkeng, J.; Donner, M.; Ojiambo, P.S.; Ikotun, B.; Augusto, J.; Cotty, P.J.; Bandyopadhyay, R. Environmental distribution and genetic diversity of vegetative compatibility groups determine biocontrol strategies to mitigate aflatoxin contamination of maize by Aspergillus flavus. Microb. Biotechnol. 2016, 9, 75-88. [CrossRef] [PubMed]

47. Agbetiameh, D.; Ortega-Beltran, A.; Awuah, R.T.; Atehnkeng, J.; Islam, M.-S.; Callicott, K.A.; Cotty, P.J.; Bandyopadhyay, R. Potential of atoxigenic Aspergillus flavus vegetative compatibility groups associated with maize and groundnut in Ghana as biocontrol agents for aflatoxin management. Front. Microbiol. 2019, 10, 2069. [CrossRef] [PubMed]

48. Cotty, P.J.; Antilla, L.; Wakelyn, P.J. Competitive exclusion of aflatoxin producers: Farmer driven research and development. In Biological Control: A Global Perspective; Vincent, C., Goettel, N., Lazarovitis, G., Eds.; CAB International: Oxfordshire, UK, 2007; pp. 241-253.

49. Mehl, H.L.; Jaime, R.; Callicott, K.A.; Probst, C.; Garber, N.P.; Ortega-Beltran, A.; Grubisha, L.C.; Cotty, P.J. Aspergillus flavus diversity on crops and in the environment can be exploited to reduce aflatoxin exposure and improve health. Ann. N. Y. Acad. Sci. 2012, 1273, 7-17. [CrossRef] [PubMed]

50. Atehnkeng, J.; Ojiambo, P.S.; Cotty, P.J.; Bandyopadhyay, R. Field efficacy of a mixture of atoxigenic Aspergillus flavus Link: FR vegetative compatibility groups in preventing aflatoxin contamination in maize (Zea mays L.). Biol. Control 2014, 72, 62-70. [CrossRef] 
51. Doster, M.A.; Cotty, P.J.; Michailides, T.J. Evaluation of the atoxigenic Aspergillus flavus strain AF36 in pistachio orchards. Plant Dis. 2014, 98, 948-956. [CrossRef]

52. Mauro, A.; Garcia-Cela, E.; Pietri, A.; Cotty, P.J.; Battilani, P. Biological control products for aflatoxin prevention in Italy: Commercial field evaluation of atoxigenic Aspergillus flavus active ingredients. Toxins 2018, 10, 30. [CrossRef]

53. Bandyopadhyay, R.; Cardwell, K.F.; Ortega-Beltran, A.; Schulthess, F.; Meikle, W.; Setamou, M.; Cotty, P.J. Identifying and managing plant health risks for key African crops: Maize. In Critical Issues in Plant Health: 50 Years of Research in African Agriculture; Neuenschwander, P., Tamò, M., Eds.; Burleigh Dodds Science Publishing: Cambridge, UK, 2019; pp. 173-212. [CrossRef]

54. Brown, R.L.; Cotty, P.; Cleveland, T.E. Reduction in aflatoxin content of maize by atoxigenic strains of Aspergillus flavus. J. Food Prot. 1991, 54, 623-626. [CrossRef] [PubMed]

55. Cotty, P.J. Virulence and cultural characteristics of two Aspergillus flavus strains pathogenic on cotton. Phytopathology 1989, 79, 808-814. [CrossRef]

56. Cotty, P.J. Biocompetitive exclusion of toxigenic fungi. In The Mycotoxin Factbook; Barug, D., Bhatnagar, D., van Egdmond, H.P., van der Kamp, J.W., van Osenbruggen, W.A., Visconti, A., Eds.; Wageningen Academic Publishers: Wageningen, The Netherlands, 2006; pp. 179-197.

57. Environmental Protection Agency. Aspergillus Flavus AF36; Amendment to Make Label Changes; 2011. Available online: https://www3.epa.gov/pesticides/chem_search/ppls/071693-00001-20110505.pdf (accessed on 15 February 2020).

58. Dorner, J.W. Development of biocontrol technology to manage aflatoxin contamination in peanuts. Peanut Sci. 2009, 36, 60-67. [CrossRef]

59. Lavkor, I.; Arioglu, H.; Var, I.; Oztemiz, S. Biological control of aflatoxigenic fungi on peanut: For the pre-harvest approach. Turkish J. Field Crop. 2019, 24, 21-27. [CrossRef]

60. Schreurs, F.; Bandyopadhyay, R.; Kooyman, C.; Ortega-Beltran, A.; Akande, A.; Konlambigue, M.; Van den Bosch, N. Commercial products promoting plant health in African agriculture. In Critical Issues in Plant Health: 50 Years of Research in African Agriculture; Neuenschwander, P., Tamò, M., Eds.; Burleigh Dodds Science Publishing: Cambridge, UK, 2019; pp. 345-364. [CrossRef]

61. Probst, C.; Bandyopadhyay, R.; Price, L.E.; Cotty, P.J. Identification of atoxigenic Aspergillus flavus isolates to reduce aflatoxin contamination of maize in Kenya. Plant Dis. 2011, 95, 212-218. [CrossRef]

62. Ortega-Beltran, A.; Cotty, P.J. Frequent shifts in Aspergillus flavus populations associated with maize production in Sonora, Mexico. Phytopathology 2018, 108, 412-420. [CrossRef]

63. Shenge, K.C.; Mehl, H.L.; Cotty, P.J. Interactions among active ingredients of a multi-isolate aflatoxin biocontrol product. Phytopathology 2017, 107, S5.131.

64. Environmental Protection Agency: Receipt of Information under the Toxic Substances Control Act. Federal Register 69059. 2016; Volume 81. Available online: https://www.govinfo.gov/app/details/FR-2016-10-05/ 2016-24112 (accessed on 10 November 2019).

65. Donner, M.; Lichtemberg, P.; Doster, M.A.; Picot, A.; Cotty, P.J.; Puckett, R.D.; Michailides, T.J. Community structure of Aspergillus flavus and A. parasiticus in major almond-producing areas of California, United States. Plant Dis. 2015, 99, 1161-1169. [CrossRef]

66. Picot, A.; Doster, M.A.; Islam, M.S.; Callicott, K.A.; Ortega-Beltran, A.; Cotty, P.J.; Michailides, T.J. Distribution and incidence of atoxigenic Aspergillus flavus VCG in tree crop orchards in California: A strategy for identifying potential antagonists, the example of almonds. Int. J. Food Microbiol. 2018, 265, 55-64. [CrossRef]

67. Molo, M.S.; Heiniger, R.W.; Boerema, L.; Carbone, I. Trial summary on the comparison of various non-aflatoxigenic strains of Aspergillus flavus on mycotoxin levels and yield in maize. Agron. J. 2019, 1-5. [CrossRef]

68. Camiletti, B.X.; Torrico, A.K.; Fernanda Maurino, M.; Cristos, D.; Magnoli, C.; Lucini, E.I.; de la Paz Giménez Pecci, M. Fungal screening and aflatoxin production by Aspergillus section Flavi isolated from pre-harvest maize ears grown in two Argentine regions. Crop Prot. 2017, 92, 41-48. [CrossRef]

69. Camiletti, B.X.; Moral, J.; Asensio, C.M.; Torrico, A.K.; Lucini, E.I.; Giménez-Pecci, M.D.L.P.; Michailides, T.J. Characterization of Argentinian endemic Aspergillus flavus isolates and their potential use as biocontrol agents for mycotoxins in maize. Phytopathology 2018, 108, 818-828. [CrossRef] [PubMed]

70. García-Lopez, M.T.; Jaime, R.; Camiletti, B.X.; Ortega-Beltran, A.; Moral, J.; Michailides, T.J. Contaminación de aflatoxinas en frutos secos: Un problema emergente. Phytoma 2018, 302, 38-42. 
71. Zhou, W.; Hu, L.; Zhao, Y.; Wang, M.; Zhang, H. Inhibition of fungal aflatoxin B1 biosynthesis by diverse botanically-derived polyphenols. Trop. J. Pharm. Res. 2015, 14, 605-609. [CrossRef]

72. Hulikunte Mallikarjunaiah, N.; Jayapala, N.; Puttaswamy, H.; Siddapura Ramachandrappa, N. Characterization of non-aflatoxigenic strains of Aspergillus flavus as potential biocontrol agent for the management of aflatoxin contamination in groundnut. Microb. Pathog. 2017, 102, 21-28. [CrossRef] [PubMed]

73. Pitt, J.; Manthong, C.; Siriacha, P.; Chotechaunmanirat, S.; Markwell, P. Studies on the biocontrol of aflatoxin in maize in Thailand. Biocontrol Sci. Technol. 2015. [CrossRef]

74. Tran-Dinh, N.; Pitt, J.I.; Markwell, P.J. Selection of non-toxigenic strains of Aspergillus flavus for biocontrol of aflatoxins in maize in Thailand. Biocontrol Sci. Technol. 2014, 24, 652-661. [CrossRef]

75. Savić, Z.; Dudaš, T.; Loc, M.; Grahovac, M.; Budakov, D.; Jajić, I.; Krstović, S.; Barošević, T.; Krska, R.; Sulyok, M.; et al. Biological control of aflatoxin in maize grown in Serbia. Toxins 2020, 12, 162. [CrossRef]

76. Grubisha, L.C.; Cotty, P.J. Genetic analysis of the Aspergillus flavus vegetative compatibility group to which a biological control agent that limits aflatoxin contamination in U.S. crops belongs. Appl. Environ. Microbiol. 2015, 81, 5889-5899. [CrossRef]

77. Mauro, A.; Battilani, P.; Cotty, P.J. Atoxigenic Aspergillus flavus endemic to Italy for biocontrol of aflatoxins in maize. BioControl 2015, 60, 125-134. [CrossRef]

78. Yu, J.; Chang, P.K.; Cary, J.W.; Wright, M.; Bhatnagar, D.; Cleveland, T.E.; Payne, G.A.; Linz, J.E. Comparative mapping of aflatoxin pathway gene clusters in Aspergillus parasiticus and Aspergillus flavus. Appl. Environ. Microbiol. 1995, 61, 2365-2371. [CrossRef] [PubMed]

79. Yu, J. Current understanding on aflatoxin biosynthesis and future perspective in reducing aflatoxin contamination. Toxins 2012, 4, 1024-1057. [CrossRef]

80. Prieto, R.; Yousibova, G.L.; Woloshuk, C.P. Identification of aflatoxin biosynthesis genes by genetic complementation in an Aspergillus flavus mutant lacking the aflatoxin gene cluster. Appl. Environ. Microbiol. 1996, 62, 3567-3571. [CrossRef] [PubMed]

81. Chang, P.K.; Horn, B.W.; Dorner, J.W. Sequence breakpoints in the aflatoxin biosynthesis gene cluster and flanking regions in nonaflatoxigenic Aspergillus flavus isolates. Fungal Genet. Biol. 2005, 42, 914-923. [CrossRef] [PubMed]

82. Ehrlich, K.C.; Cotty, P.J. An isolate of Aspergillus flavus used to reduce aflatoxin contamination in cottonseed has a defective polyketide synthase gene. Appl. Microbiol. Biotechnol. 2004, 65, 473-478. [CrossRef] [PubMed]

83. Tominaga, M.; Lee, Y.-H.; Hayashi, R.; Suzuki, Y.; Yamada, O.; Sakamoto, K.; Gotoh, K.; Akita, O. Molecular analysis of an inactive aflatoxin biosynthesis gene cluster in Aspergillus oryzae RIB strains. Appl. Environ. Microbiol. 2006, 72, 484-490. [CrossRef]

84. Mehl, H.L.; Cotty, P.J. Variation in competitive ability among isolates of Aspergillus flavus from different vegetative compatibility groups during maize infection. Phytopathology 2010, 100, 150-159. [CrossRef]

85. Mehl, H.L.; Cotty, P.J. Influence of plant host species on intraspecific competition during infection by Aspergillus flavus. Plant Pathol. 2013, 62, 1310-1318. [CrossRef]

86. Sweany, R.R.; Damann, K.E.; Kaller, M.D. Comparison of soil and corn kernel Aspergillus flavus populations: Evidence for niche specialization. Phytopathology 2011, 101, 952-959. [CrossRef] [PubMed]

87. Bandyopadhyay, R.; Atehnkeng, J.; Ortega-Beltran, A.; Akande, A.; Falade, T.D.O.; Cotty, P.J. "Ground-truthing" efficacy of biological control for aflatoxin mitigation in farmers' fields in Nigeria: From field trials to commercial usage, a 10-year study. Front. Microbiol. 2019, 10, 2528. [CrossRef]

88. Senghor, L.A.; Ortega-Beltran, A.; Atehnkeng, J.; Callicott, K.A.; Cotty, P.J.; Bandyopadhyay, R. The atoxigenic biocontrol product Aflasafe SN01 is a valuable tool to mitigate aflatoxin contamination of both maize and groundnut cultivated in Senegal. Plant Dis. 2019, 104, 510-520. [CrossRef] [PubMed]

89. Ortega-Beltran, A.; Bandyopadhyay, R. Comments on "Trial summary on the comparison of various non-aflatoxigenic strains of Aspergillus flavus on mycotoxin levels and yield in maize" by M.S. Molo, et al. Agron. J. 111: 942-946 (2019). Agron. J. 2019, 111, 2625-2631. [CrossRef]

90. Weaver, M.; Abbas, H.K. Field displacement of aflatoxigenic Aspergillus flavus strains through repeated biological control applications. Front. Microbiol. 2019, 10, 1788. [CrossRef] [PubMed]

91. Dorner, J.W. Biological control of aflatoxin contamination of crops. J. Toxicol. Toxin Rev. 2004, 23, 425-450. [CrossRef] 
92. Dorner, J.W.; Cole, R.J.; Connick, W.J.; Daigle, D.J.; McGuire, M.R.; Shasha, B.S. Evaluation of biological control formulations to reduce aflatoxin contamination in peanuts. Biol. Control 2003, 26, 318-324. [CrossRef]

93. Dorner, J.W.; Cole, R.J.; Blankenship, P.D. Use of a biocompetitive agent to control preharvest aflatoxin in drought stressed peanuts. J. Food Prot. 1992, 55, 888-892. [CrossRef]

94. Bock, C.H.; Cotty, P.J. Wheat seed colonized with atoxigenic Aspergillus flavus: Characterization and production of a biopesticide for aflatoxin control. Biocontrol Sci. Technol. 1999, 9, 529-543. [CrossRef]

95. Jaime, R.; Foley, M.; Barker, G.; Liesner, L.; Antilla, L.; Bandyopadhyay, R.; Cotty, P.J. Evaluation of residence, sporulation and efficacy of two formulations of the biocontrol Aspergillus flavus AF36 in commercial cotton fields in Arizona. Phytopathology 2014, 104, S3.55. [CrossRef]

96. Accinelli, C.; Abbas, H.K.; Little, N.S.; Kotowicz, J.K.; Mencarelli, M.; Shier, W.T. A liquid bioplastic formulation for film coating of agronomic seeds. Crop Prot. 2016, 89, 123-128. [CrossRef]

97. Accinelli, C.; Abbas, H.K.; Little, N.S.; Kotowicz, J.K.; Shier, W.T. Biological control of aflatoxin production in corn using non-aflatoxigenic Aspergillus flavus administered as a bioplastic-based seed coating. Crop Prot. 2018, 107, 87-92. [CrossRef]

98. Okike, I.; Samireddypalle, A.; Kaptoge, L.; Fauquet, C.; Atehnkeng, J.; Bandyopadhyay, R.; Kulakow, P.; Duncan, A.; Alabi, T.; Blummel, M. Technical innovations for small-scale producers and households to process wet cassava peels into high quality animal feed ingredients and aflasafe ${ }^{\mathrm{TM}}$ substrate. Food Chain 2015, 5, 71-90. [CrossRef]

99. Michailides, T.J.; Puckett, R.D.; Moral, J.; García-Lopez, M.T.; Felts, D.; Doster, L.; Jaime, R. Factors Affecting the Efficacy of AF36 Improvement of the Biocontrol Agent and Monitoring Commercial Application. 2018. Available online: https://americanpistachios.org/sites/default/files/inlinefiles/5.\%20Factors\%20Affecting\% 20the $\% 20$ Efficacy $\% 20$ of $\% 20$ AF36\%20Improvement $\% 20$ of $\% 20$ the $\% 20$ Biocontrol $\% 20$ Agent $\% 20$ and $\%$ 20Monitoring\%20Commercial\%20Applications_Edited\%2001-04-2018.pdf (accessed on 15 January 2020).

100. Ezekiel, C.N.; Ortega-Beltran, A.; Oyedeji, E.; Atehnkeng, J.; Kössler, P.; Tairu, F.; Hoeschle-Zeledon, I.; Karlovsky, P.; Cotty, P.J.; Bandyopadhyay, R. Aflatoxin in chili peppers in Nigeria: Extent of contamination and control using atoxigenic Aspergillus flavus genotypes as biocontrol agents. Toxins 2019, 11, 429. [CrossRef] [PubMed]

101. Dorner, J.W. Simultaneous quantitation of Aspergillus flavus/A. parasiticus and aflatoxins in peanuts. J. AOAC Int. 2002, 85, 911-916. [CrossRef] [PubMed]

102. Atehnkeng, J.; Ojiambo, P.S.; Ikotun, T.; Sikora, R.A.; Cotty, P.J.; Bandyopadhyay, R. Evaluation of atoxigenic isolates of Aspergillus flavus as potential biocontrol agents for aflatoxin in maize. Food Addit. Contam. Part A Chem. Anal. Control. Expo. Risk Assess. 2008, 25, 1264-1271. [CrossRef] [PubMed]

103. Nelson, M.R.; Orum, T.V.; Jaime-Garcia, R.; Nadeem, A. Applications of geographic information systems and geostatistics in plant disease epidemiology and management. Plant Dis. 1999, 83, 308-319. [CrossRef]

104. Jaime, R.; Cotty, P.J. Temporal dynamic of Aspergillus flavus community structure in soils of fields treated with the atoxigenic biocontrol A. flavus AF36 in Arizona. Phytopathology 2013, 103, S2.66. [CrossRef]

105. Bidartondo, M.I.; Ellis, C.; Kennedy, P.G.; Lilleskov, E.A.; Suz, L.M.; Andrew, C. Climate change: Fungal responses and effects. In State of the World's Fungi; Kew Garden: London, UK, 2018; pp. 62-72.

106. Alcamo, J.; Henrichs, T.; Rösch, T. World Water in 2025-Global Modeling and Scenario Analysis for the World Commission on Water for the 21st Century; Report A0002; Center for Environmental Systems Research, University of Kassel: Kassel, Germany, 2000; p. 65.

107. Jaime-Garcia, R.; Cotty, P.J. Aflatoxin contamination of commercial cottonseed in south Texas. Phytopathology 2003, 93, 1190-1200. [CrossRef]

108. Jaime-Garcia, R.; Cotty, P.J. Crop rotation and soil temperature influence the community structure of Aspergillus flavus in soil. Soil Biol. Biochem. 2010, 42, 1842-1847. [CrossRef]

109. Ortega-Beltran, A.; Grubisha, L.C.; Callicott, K.A.; Cotty, P.J. The vegetative compatibility group to which the US biocontrol agent Aspergillus flavus AF36 belongs is also endemic to Mexico. J. Appl. Microbiol. 2016, 120, 986-998. [CrossRef]

110. Islam, M.-S.; Callicott, K.A.; Mutegi, C.; Bandyopadhyay, R.; Cotty, P.J. Aspergillus flavus resident in Kenya: High genetic diversity in an ancient population primarily shaped by clonal reproduction and mutation-driven evolution. Fungal Ecol. 2018, 35, 20-33. [CrossRef]

111. Horn, B.W. Sexual reproduction in Aspergillus flavus. Mycologia 2009, 101, 423-429. [CrossRef] [PubMed] 
112. Horn, B.W.; Ramirez-Prado, J.H.; Carbone, I. Sexual reproduction and recombination in the aflatoxin-producing fungus Aspergillus parasiticus. Fungal Genet. Biol. 2009, 46, 169-175. [CrossRef] [PubMed]

113. Olarte, R.A.; Horn, B.W.; Dorner, J.W.; Monacell, J.T.; Singh, R.; Stone, E.A.; Carbone, I. Effect of sexual recombination on population diversity in aflatoxin production by Aspergillus flavus and evidence for cryptic heterokaryosis. Mol. Ecol. 2012, 21, 1453-1476. [CrossRef] [PubMed]

114. Moore, G.G.; Elliott, J.L.; Singh, R.; Horn, B.W.; Dorner, J.W.; Stone, E.A.; Chulze, S.N.; Barros, G.G.; Naik, M.K.; Wright, G.C.; et al. Sexuality generates diversity in the aflatoxin gene cluster: Evidence on a global scale. PLoS Pathog. 2013, 8. [CrossRef]

115. Horn, B.W.; Sorensen, R.B.; Lamb, M.C.; Sobolev, V.S.; Olarte, R.A.; Worthington, C.J.; Carbone, I. Sexual reproduction in Aspergillus flavus sclerotia naturally produced in corn. Phytopathology 2014, 104, 75-85. [CrossRef]

116. Njoroge, S.M.C. A critical review of aflatoxin contamination of peanuts in Malawi and Zambia: The past, present, and future. Plant Dis. 2018, 102, 2394-2406. [CrossRef]

117. Ehrlich, K.C.; Moore, G.G.; Mellon, J.E.; Bhatnagar, D. Challenges facing the biological control strategy for eliminating aflatoxin contamination. World Mycotoxin J. 2015, 8, 225-233. [CrossRef]

118. Kagot, V.; Okoth, S.; De Boevre, M.; De Saeger, S. Biocontrol of Aspergillus and Fusarium mycotoxins in Africa: Benefits and limitations. Toxins 2019, 11, 109. [CrossRef]

119. Ndemera, M.; De Boevre, M.; De Saeger, S. Mycotoxin management in a developing country context: A critical review of strategies aimed at decreasing dietary exposure to mycotoxins in Zimbabwe. Crit. Rev. Food Sci. Nutr. 2020, 60, 529-540. [CrossRef]

120. Pitt, J. The pros and cons of using biocontrol by competitive exclusion as a means for reducing aflatoxin in maize in Africa. World Mycotoxin J. 2019, 12, 103-112. [CrossRef]

121. Savary, S.; Willocquet, L.; Pethybridge, S.J.; Esker, P.; McRoberts, N.; Nelson, A. The global burden of pathogens and pests on major food crops. Nat. Ecol. Evol. 2019, 3, 430-439. [CrossRef] [PubMed]

(C) 2020 by the authors. Licensee MDPI, Basel, Switzerland. This article is an open access article distributed under the terms and conditions of the Creative Commons Attribution (CC BY) license (http://creativecommons.org/licenses/by/4.0/). 